\title{
The quality of groundwater in rural areas and its impact on the functioning of local water intakes
}

\author{
Robert Nowak $^{1, *}$, and Anna Imperowicz-Pawlaczyk ${ }^{1}$ \\ ${ }^{1}$ Department of Environmental Technologies and Bioanalitycs, Faculty of Civil Engineering, Environmental and Geodetic Sciences, \\ Technical University of Koszalin, Sniadeckich 2, 75-453 Koszalin, Poland
}

\begin{abstract}
The main purpose of this paper is to indicate the impact of changes in the quality of groundwater intakes on the functioning of rural water supply systems. In particular, the important factors for the groundwater quality in rural areas have been presented. Results of research on the quality parameters of groundwater, obtained in $2012 \div 2016$ for selected small water intakes in north-western Poland, were presented. The quality of groundwater in the subsequent analyzed years was deteriorating. There was an increase in the content of iron and manganese compounds, ammonium ions, as well as the presence of bacteriological contaminants in test water samples. For these reasons, problems with providing the receivers with water of appropriate quality parameters have been reported in described rural intakes. The paper is an attempt to show the relationship between the type and magnitude of changes in the quality of groundwater and the efficiency of the treatment plant. In addition, pro-quality activities undertaken by local water companies were emphasized.
\end{abstract}

\section{Introduction}

The quality of tap water depends on several factors. The source of water intake, method and the condition of the intake, as well as the efficiency of the water treatment process, should all be taken into consideration. The state of the whole water distribution system is also important. The study of the composition and properties of water intended for drinking is now a routine task for water companies [1].

Over the last decades, more and more villages have been using water supplies. Unfortunately, the construction of collective sewerage and treatment systems has not kept pace with the construction of water supply systems [2]. In rural areas, sewage is generally directed to cesspits, but also to rivers and ponds, often directly to the aerating zone. This results in contamination of the receiving water and land. Sometimes this contamination makes it impossible to use local water resources [3,4]. Land use also affects the qualitative and quantitative status of groundwater resources. Point sources of hazardous chemicals are particularly important [5]. For these reasons, water management in rural areas should be related to the protection of the quality and quantity of water resources. In this area, there is a need for the development of scientific research. This research should aim to explain the impact of farming activities, biological progresses, agro-technical methods, land use, etc. on local groundwater and surface water resources [6]. Intensive and long-term investment in the resources and protection of groundwater quality are also urgently needed [7].

\section{Factors that shape groundwater quality in rural areas}

In the case of residents of rural areas, the drinking water supply is most often provided through small systems, based on groundwater intakes. In such systems, cases of supplying water with unstable quality parameters are more frequently reported. These problems are often associated with the state of local groundwater resources.

The deteriorating quality of groundwater may have natural causes, but are mainly due to anthropogenic factors. The release and migration of pollutants from surface sources (in particular, cultivation and fertilization of soil and animal breeding) and on-farm activities in rural areas should be mentioned here [8].

For these reasons, aquifers are susceptible to landfill and waste water discharges due to the development of housing and the intensification of agriculture. Important factors for the quality of groundwater are considered: the management of organic and mineral fertilizers and compliance with sanitary regulations concerning the establishment of direct protection zones around water intakes. Problems in this area are present both in Poland and in many other regions of the world $[9,10,11]$. It should be noted that as a result of administrative decisions taken in Poland in 2010, zones of protection of groundwater intakes have been lost, resulting in the degradation of water resources [12].

The causes of deterioration of groundwater quality may be due to changes in the water circulation system, hydrogeochemical changes and the impact of pollutants. Increases in $\mathrm{Fe}$ and $\mathrm{Mn}$ concentrations may be due to

Corresponding author: robert.nowak@tu.koszalin.pl 
changes in the water circulation system caused by the mixing of waters from various hydrogeochemical environments (often ammonium nitrate levels, for example, may also increase). The greatest changes in water quality occur as a result of the lowering of the water table during the operation and activation of oxidation processes of sulfides and organic substances. Impacts of anthropogenic impurities are most likely to occur in open and poorly insulated aquifers [13].

An important factor influencing water quality in a given area can be hydrogeochemical changes in the conditions where water is abstracted. Under such conditions, increased levels of nitrates and sulphates can occur in water. Differentiated distribution of nitrate concentrations in the water from rural wells is a result of land development. Sometimes, as a result of hydrogeochemical changes, the chlorine concentration, which is an indicator of anthropogenic pollutants, may also increase [8]. Chloride concentration is highest in waters exposed to pollution from domestic sources. The lowest concentrations are recorded in water in the least populated and non-agricultural areas. Chlorides, by their conservative properties, allow the tracking of the speed and direction of movement of both the water and the substances present therein. However, in the studies on water quality in rural areas, chloride concentrations are often not taken into account. The potential of the data received to identify the sources and fates of substances that negatively affect water quality is also not used [14].

There may be significant degradation in the quality of groundwater due to the impact of pollutants, both large and small, linear and point. Potential foci of pollutants may be located in areas of intensive farming, in areas without collective sewerage and in the vicinity of wastewater discharges. This is also true in areas in which are situated breeding farms, factories and petrol stations. The quality of water can also be affected by landfills [15]. Among the pollutants of groundwater, organic pollutants, including pesticides, should be mentioned. Groundwater susceptibility to these types of impurities depends on natural factors and the properties of the pesticides [16].

Nitrogen compounds, in particular ammonium and nitrates, are basic indicators of the quality of groundwater. The origin of ammonium ions in water can be both natural and anthropogenic. The requirement for low concentrations of these ions in drinking water is primarily due to health reasons. It should be noted that excessive amounts thereof can also lead to secondary pollution of the water (through oxygen consumption and the development of anaerobic bacteria). Detection of ammonium ions in groundwater, where these ions have not previously been identified, most often means contamination of these waters with sewage. This applies particularly to areas of intensive livestock farming, agricultural crops or landfills. Counteracting and reducing the impact of point sources of pollution (mainly those associated with animal production) on rural areas must be associated with monitoring these contaminants [17]. It should be noted that increased concentrations of fertilizer components can endure in contaminated water for a long time, even if commercial farming has been abandoned and farming or breeding is only carried out for personal use [18].

Near point contamination sources, there is a significant variation of the vertical water chemistry, especially in the first (subsurface) aquifer. Identification of processes that shape the subsurface aquifer chemistry may be based on multivariate analysis of the factor. The analysis should take into account a number of data: water chemistry, hydrogeological conditions and forms of land use [19]. In the migration of pollutants, the thickness of the soil layer and the thickness of the aeration zone play a significant role [20,21]. The large vertical variation of the chemical composition of groundwater in the first aquifer has been demonstrated in hydrogeological research [22]. The removal of chemicals from the aeration zone has been observed, particularly with an increase in the depth of sampling the concentration of nitrates, nitrites, sodium and potassium has decreased. The inverse dependence was noted for the concentration of silica, iron and manganese, i.e., ions, penetrating into groundwater due to long-term interaction: the rock-groundwater. In water in rural areas, as opposed to sewerage areas, the concentration of nitrate nitrogen was higher than the concentration of nitrite nitrogen, which occurred in each aquifer. This relationship was observed in each aquifer and indicates that there are conditions that allow a faster transition of nitrogen compounds to oxidized forms. This occurrence may be augmented by other sources of pollution, for example, farming (agricultural fertilization, animal breeding) or poorly developed sewerage infrastructure [21]. Among the factors that are important for the flow of pollutants, the most important should be considered to be the type of production and its intensity and the conditions of land use. Local hydrological and hydrodynamic conditions and physiographic elements that condition infiltration are also important [23]. The spatial distribution of water hazards can be characterized by a high variability for a particular area. Water security at certain times can be influenced by different factors: the distribution of surface water supply, dehydration of groundwater, sanitation, irrigation and the properties of the water [24].

Shallow groundwater, due to its susceptibility to contamination and poor isolation from the penetration of pollutants from the ground surface, may be an indicator of the agriculture impact on the environment [25]. It should be noted that the impact of agricultural activity on the composition of groundwater shows high spatial variability [26]. In shallow groundwater in rural areas, particular attention is paid to the exceedance of drinking water values of nitrate nitrogen concentrations. This happens in wells located near to farm buildings [27]. Nitrate contamination is then the result of incorrect sewage management, including inadequately protected slurry on rural farms [20]. Inadequate water quality in poorly secured wells in non-urbanized areas may also be manifested by excess levels of iron and manganese compounds [28]. Water of the appropriate quality is most often obtained by exploiting deep wells which are appropriately located and isolated from potential pollutants [10]. Excessive concentration of nitrate in the 
water intake may result from other causes than the low level of the water table. It can result from weak security of the well [29]. There have been cases of wastewater introduction through poorly protected old wells or open piezometers, directly into the aquifer. Such action poses a serious risk to the quality of groundwater. In addition, as well as the increase in ammonia concentration, other water quality indicators (e.g. microbiological indicators) deteriorate.

One of the most dangerous sources of water contamination by nitrogen compounds is the manner of storage of livestock manure. In Poland, this method of manure management is often practiced. This is due to insufficient awareness and ignorance of farmers. Investment in manure slabs and liquid manure tanks does not solve the problem. Proper manure management should be consistent with the principles of good farming practice [30]. It has been found that long-term storage of manure (on the ground, in a pile) results in severe soil and groundwater pollution with nitrogen compounds, in particular nitrogen and ammonium nitrate. At the same time, short-term (half-yearly) storage of manure in the pile did not pose a serious threat to water quality. For these reasons, with a view to the protection of water quality, livestock manure should not be stored directly on the ground for extended periods (short-term collection is considered acceptable, but verification needs to be made on the basis of additional testing) [31].

The impact of anthropogenicity on groundwater pollution can also be significant away from farms. Water samples, taken in such places, may confirm (and often do confirm) the assumption of local impact of such pollutants. The lack of proper water and sewage management is a decisive factor in water pollution [32]. The problem of groundwater quality is often noted in the vicinity of settlement units, where the management of domestic sewage mainly takes place through a sewage holding tank system. The relationship between wastewater management and the quality of groundwater can be unequivocally demonstrated. It is confirmed by the presence of indicator bacteria in waters, adjacent to leaky tanks and uncontrolled discharges of wastewater into the environment [33]. It is also possible to use isotopic and geochemical properties, especially with respect to nitrates $\left(\mathrm{NO}_{3}^{-}\right)$[34]. In Poland, the scale of uncontrolled discharge of wastewater into the environment is huge. The problem of the impact of such activities on the groundwater quality has been widely discussed in post-mentioned work [35].

Due to the problems associated with the use of groundwater resources in rural areas, the management of these resources should be integrated into regional spatial planning. The aim should be to achieve a balance between ecological and engineering approaches [36]. Among others, the changes in water quality should be continuously monitored to ensure optimum use of sources. When it is justified and possible, the exploited source should be replaced by sources of better quality [37]. It is also recommended that groundwater intake in rural areas be related to levels of aquifer replenishment.

\section{The quality of groundwater in the aspect of the functioning of selected rural water intakes}

The small water intakes presented in this work are typical rural systems, based on the groundwater. In the first decade of the $21 \mathrm{st}$ century, the quality of the groundwater was high enough that, in the described intakes, water did not require pro-quality activities. Water was directly channeled to the customers. In other places, water was effectively treated in water treatment plants, by aeration, subsequent filtration and final disinfection. However, in recent years there has been a significant deterioration in the quality of the intake water. Lower water quality and limited local water resources have resulted in difficulties in supplying residents with drinking water of the required quality [38]. These issues are presented in the following part of the work.

Delivery of drinking water to the inhabitants of A village (137 people) takes place through a groundwater intake, consisting of one well at a depth of $39.0 \mathrm{~m}$ below ground level. The well has been in operation since 1981 . The aquifer is in the form of gravel, where the water flows under pressure. The aquifer is located within Quaternary deposits. The quality problems of this water are related, among others, to the content of ammonium ions in the intake water. These ions are present in the water in the form of N-NH4. The concentration of ammonium ions in water has increased several times in recent years. In 2016 it reached a value of $2700 \mu \mathrm{g} / 1$ (Fig. 1) [39].

In the authors' view, the causes of the presented qualitative changes in water may be the result of transformation of the local hydrogeochemical environment and the changes in the water circulation system caused by the mixing of waters from various hydrogeochemical environments.

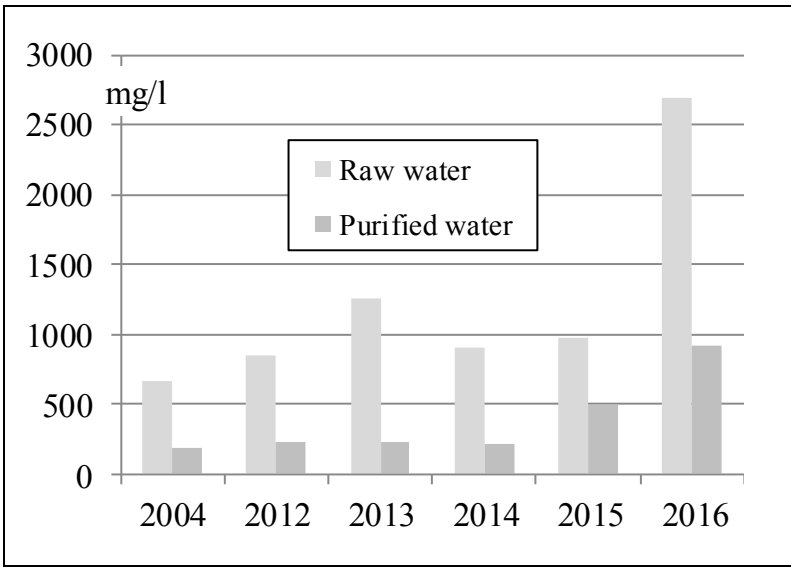

Fig. 1. The concentration of ammonium ions in the raw and treated water in A, the year 2004 and the years 2012-2016.

The above thesis is confirmed by the results of the investigations into iron and manganese concentrations (described below) which, as a result of described 
changes in the water-soil environment (i.e. with ammonium ion), were also increased [13]. It is also important that the water is only taken through one well, which drains the groundwater resources only in one place. The local water company decided to use ion exchange columns to obtain the required water treatment parameters. The authors consider the adopted solution to be appropriate, taking into account technical and economical aspects. Removing the ammonium ions in the process of intensive aeration of water would be ineffective in the given situation (the ammonium ion is in the form of N-NH4). In addition, high concentrations of N-NH4 would make it difficult to remove them during the process of water filtration, i.e. during iron and manganese removal.

In A village, in addition to the problems of raw water quality presented, increased concentrations of iron and manganese (to a lesser degree) have been found in the water in recent years. The most likely cause of the changes has been previously presented by the authors of the work. Within the period of ten years (from 2004 to 2014) the concentration of iron in water increased several times, reaching a level of $4500 \mathrm{mg} / \mathrm{l} \mathrm{Fe}$ in 2016. This increase had a significant impact on the effects of water treatment (Fig. 2) [39].

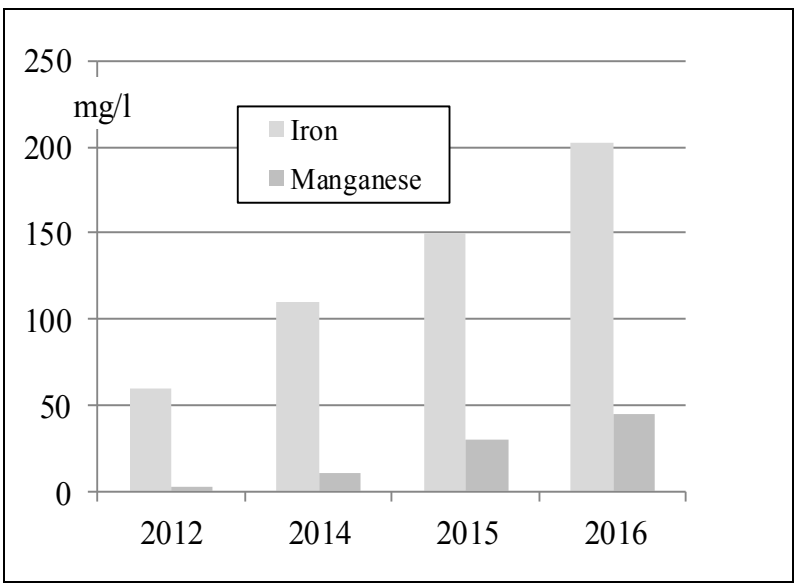

Fig. 2. The concentration of iron and manganese in purified water in A; the year 2012 and the years 2012-2016.

Modifications in the water treatment station included a reduction in filtration rate, frequent washing of the filter beds as a result of clogging of the filters and the necessity to frequently clean the aerators or replacement of them. In addition, to improve the aeration process in the air/water mixer, the amount of oxygen supplied was increased.

A different qualitative problem, concerning the intake water, was found in B village. The local water intake supplies water to three villages, inhabited by a total of 524 inhabitants. Until recently, the intake water to customers was supplied without treatment, because the water quality met the appropriate quality requirements. It should be added that water is taken from one well (43 m deep below ground level which has been in operation since 1975). The concentration of nitrate in the intake water increased gradually from 1989 to 2016 (Fig. 3) [39].
The cause of the qualitative changes in water is, according to the authors, the agricultural activity around the location of the water intake (cereal and strawberry cultivation, fertilization). In addition, long-term storage of manure took place near the water intake. An ion exchange process was used to improve the water quality: the owner installed two ion exchange columns, and regenerated the bed with brine. However, the situation should not be considered to be controlled. Since 2014, besides elevated nitrate concentrations, coliforms and escherichia coli appear sporadically in the water being tested. The effect is to close the intake for the time taken to disinfect the water. During the shutdown period, water is delivered to the customers in barrels. The presence of bacteria is related to poorly managed sewage management in the nearest rural areas [35].

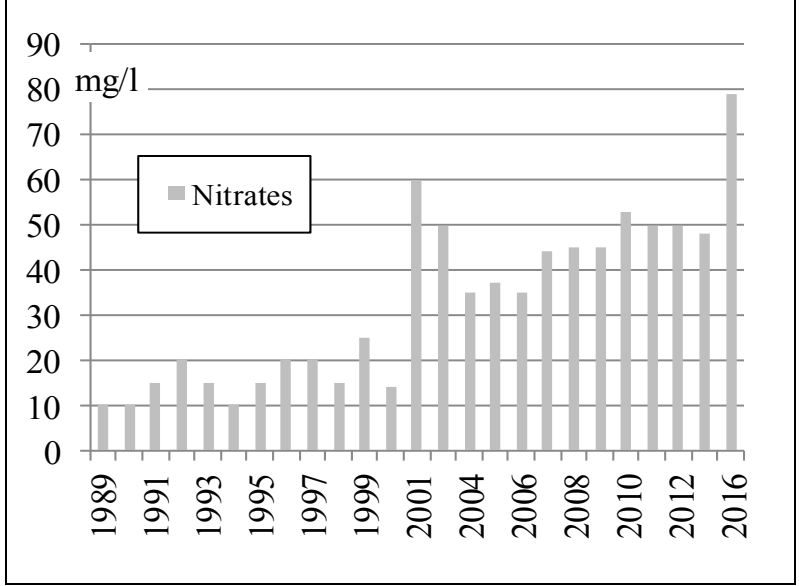

Fig. 3. The concentration of nitrates in raw water in B; the years $1989 \div 2016$.

The water from the intake in $\mathrm{C}$ village is supplied to two villages with a total population of 133 inhabitants. Commencing in 2016, excessive concentrations of manganese have been observed in the water and, in addition, microbial contamination is increasingly occurring in the water (this problem has been observed since March 2015). There are two wells - the first well with a depth of $28 \mathrm{~m}$ below ground level, currently working as a back-up (drilled in 1966) and the second well with a depth of $24 \mathrm{~m}$ below ground level (in operation since 1969). From October 2016, the total number of bacteria in the treated water is constantly above $100 \mathrm{cfu} / 1 \mathrm{ml}$ despite cyclical disinfection of the wells. There are also coliforms present in amounts of $2 \div 3 \mathrm{cfu} / 100 \mathrm{ml}$ to $15 \mathrm{cfu} / 100 \mathrm{ml}$. The bacteriological hazard of water was eliminated by continuous water disinfection with chlorine. According to a geological study [40], neither well in C village has natural insulation. The water intake includes the upper interglacial level, which is in the region of the uncovered level. In this case, the location of the intake and its geological characteristics are extremely important for water safety, particularly from a microbiological point of view. This is due to inadequate sewage management in the nearest villages. In the vicinity of this water intake (the nearest villages), the scale of leakage of sewage 
collection and treatment system is over 90\% [35]. For these reasons, the authors stress the important role of protection zones, both direct and indirect. In the case of the described water intake, these zones could reduce the negative impact of wastewater on the quality of groundwater.

The water intake in D village supplies the water to the 141 residents of this village. The groundwater is taken from a depth of $37 \mathrm{~m}$ below ground level through a drilled well. The well has been operational since 1969 . The water is directed to a water treatment plant where it is treated in a conventional system. However, the increase in the concentration of iron in the intake water (from $2500 \mu \mathrm{g} \mathrm{Fe} / 1$ in 2012 to $5110 \mu \mathrm{g} \mathrm{Fe} / 1$ in 2016) has caused operational problems at the WTP. The deterioration in the quality of the water is due to changes in the local hydrogeochemical environment. It is also the effect of the intake of water from one well. The consequence of these phenomena was the deterioration in the efficiency of water treatment. The concentration of manganese in treated water increased. Within the proquality activities, the pressure filter was replaced, and an additional water-air mixer was installed to increase the effectiveness of manganese removal from water. It was assumed that the problems with manganese were due to an excessively low concentration of oxygen in the water. The amount of oxygen in the water after the iron removal process was insufficient to oxidize the manganese. In order to remove iron from the water efficiently (despite the continuous increase of its concentration in raw water), the velocity of water flow through the filter bed has been reduced. At the same time, a high frequency of degasser cleaning was adopted. Large amounts of precipitated iron were deposited on elements of equipment and pipes (Fig. 4).

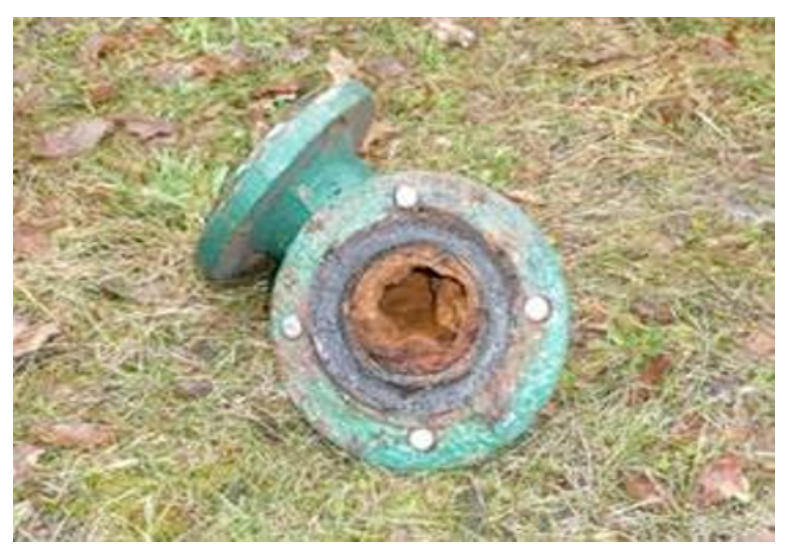

Fig. 4. The part of the installation (elbow) from the water treatment plant in $\mathrm{D}$.

In E village, there is a water intake, supplying 162 residents of the village with water for consumption. The water intake is based on one well with a depth $116.5 \mathrm{~m}$ below ground level. The well has been in operation since 1976. Up to 2006, the water was directed to the recipients without treatment. In that year, in order to provide customers with water of a suitable quality, a water treatment system was installed. The system was based on aeration and water filtration in pressurized equipment. Silica sand and G-1 catalytic mass were used to fill the filter bed. By 2014, the iron concentration in the water was at a more or less constant level. It ranged from 300 to $400 \mu \mathrm{g} \mathrm{Fe} / \mathrm{l}$. However, in 2015 the iron concentration increased to $745 \mu \mathrm{g} \mathrm{Fe} / \mathrm{l}$. In the next year, an increase in the manganese concentration in intake water was found $(434 \mu \mathrm{g} / \mathrm{l} \mathrm{Mn})$. During the previous three years the average manganese concentration was $200 \mu \mathrm{g} / 1 \mathrm{Mn}$. (It varied between 150 and $220 \mu \mathrm{g} / \mathrm{l} \mathrm{Mn}$ ) It is the opinion of the authors that the significant increase in iron and manganese concentrations in water is due to similar reasons to those presented in $\mathrm{A}$ and $\mathrm{D}$ villages.

The summary table (Tabela 1) of checked water quality and changes, for all described water intakes, it was placed below.

Table 1. The changes in water quality - a summary.

\begin{tabular}{|c|c|c|}
\hline \multicolumn{3}{|l|}{ A village } \\
\hline The concentration $(\mu \mathrm{g} / \mathrm{l})$ in year: & 2004 & 2016 \\
\hline ammonium in raw water & 660 & 2700 \\
\hline ammonium in treated water & 180 & 920 \\
\hline The concentration $(\mu \mathrm{g} / \mathrm{l})$ in year: & 2004 & 2016 \\
\hline iron in raw water & 1100 & 4500 \\
\hline The concentration $(\mu \mathrm{g} / 1)$ in year: & 2012 & 2016 \\
\hline iron in treated water & 60 & 203 \\
\hline manganese in treated water & 2 & 45 \\
\hline \multicolumn{3}{|l|}{ B village } \\
\hline The concentration $(\mathrm{mg} / \mathrm{l})$ in year: & 1989 & 2016 \\
\hline nitrate in raw water & 10 & 73 \\
\hline Bacteria $(\mathrm{cfu} / 100 \mathrm{ml})$ in year: & \multicolumn{2}{|c|}{2014} \\
\hline escherichia coli, coliforms & \multicolumn{2}{|c|}{ sporadically } \\
\hline \multicolumn{3}{|l|}{ C village } \\
\hline Bacteria $(\mathrm{cfu} / 100 \mathrm{ml})$ in year: & \multicolumn{2}{|c|}{2016} \\
\hline the total number of bacteria & \multicolumn{2}{|c|}{ to 100} \\
\hline coliforms & \multicolumn{2}{|c|}{ to 15} \\
\hline \multicolumn{3}{|l|}{ D village } \\
\hline The concentration $(\mu \mathrm{g} / \mathrm{l})$ in year: & 2012 & 2016 \\
\hline iron in raw water & 2500 & 5110 \\
\hline \multicolumn{3}{|l|}{ E village } \\
\hline The concentration $(\mu \mathrm{g} / \mathrm{l})$ in year: & to 2014 & 2015 \\
\hline iron in raw water & $300-400$ & 745 \\
\hline The concentration $(\mu \mathrm{g} / \mathrm{l})$ in year: & to 2015 & 2016 \\
\hline manganese in raw water & $150-220$ & 434 \\
\hline
\end{tabular}

\section{Conclusions}

- The quality of groundwater in rural areas is strongly dependent on anthropogenic factors, particularly the type and intensity of agricultural activities and the method of wastewater management. For example, in B village a high nitrate concentration in water was found. The concentration of these compounds in the intake water increased gradually from 1989 (10 mg N-NO3/1) to 2016 (73 mg N-NO3/1). Since 2014, besides elevated nitrate concentrations, coliforms and escherichia coli appear sporadically in the water being tested. The cause of the qualitative changes in water is, according to the authors, the agricultural activity (cereal and strawberry cultivation, fertilization) and long-term storage of manure around the location of the water intake.

- The major water quality problem in small water supply 
systems is the high concentrations of iron, manganese, nitrogen compounds (nitrates and ammonium) and bacteriological contamination. For example, in E village the iron concentration in the water was at a more or less constant level by 2014 (it ranged from 300 to $400 \mu \mathrm{g} \mathrm{Fe} / \mathrm{l})$. However, in 2015 the iron concentration increased to $745 \mu \mathrm{g} \mathrm{Fe} / \mathrm{l}$. In the next year, an increase in the manganese concentration in intake water was found (434 $\mu \mathrm{g} / \mathrm{l} \mathrm{Mn})$. During the previous three years the average manganese concentration was $200 \mu \mathrm{g} / 1 \mathrm{Mn}$.

- In rural water supply systems, protection zones are required, both direct and indirect. The zones could reduce the degradation of groundwater resources (especially shallow groundwater).

- Continuous monitoring of the quality of the water taken is required. This is very important for small water intakes, especially where one well is used. This is related to a decrease in the quality of intake water, which negatively affects the efficiency of its treatment systems. For example, in D village the increase in iron concentration in the intake water (from $2500 \mu \mathrm{g} \mathrm{Fe} / 1$ in 2012 to $5110 \mu \mathrm{g} \mathrm{Fe} / 1$ in 2016) has caused operational problems at the WTP. In particular, an increase in the concentration of manganese in treated water was observed. In D village, the deterioration in the quality of the water is also the effect of the intake of water from one well.

- It is recommended for water intakes equipped with one well, that they be supplemented with more wells. Additional wells can help with the work of the intake of water (e.g. alternate pump work, security in case of failure and reduce overexploitation of the aquifer).

\section{References}

1. E. Radzka, J. Jankowska, Adm. Zarządz. 107, (2015)

2. GUS. Warszawa. Ochr. Środ. 2016, (2017)

3. Z. Michalczyk, Woda Środ. Obsz. Wiejs. 4, 11 (2004)

4. R. Nowak, A. Imperowicz, Instal 364, 7/8 (2015)

5. D.N. Lerner, B. Harris, LUP 26, 1 (2009)

6. W. Mioduszewski, Woda Środ. Obsz. Wiejs. 6, 1 (2006)

7. S.S.D. Foster, P. J. Chilton, Philosophical Transaction B of The Royal Society B (2003)

8. M. Guzik, Biuletyn PIG 432, (2008)

9. E. Muntean, T. Mihaiescu, Environm. Eng. Manag. J. 15, 12 (2016)

10. J. Raczuk, K. Sarnowska, Arch. Ochr. Środ. 28, 3 (2002)

11. L.L. Gan, CHIM Oggi 34, 6B (2016)

12. M. Gutry-Korycka, A. Sadurski, Z.W. Kundzewicz, J. Pociask-Karteczka, L. Skrzypczyk, Nauka 1, (2014)
13. J. Górski, Zaopatrz. w wode jakość i ochr. wód: zag. wspótcz. (ed. M.M. Sozański, Poznań, 2010)

14. A. Sapek, Woda Środ. Obsz. Wiejs. 8, 1 (2008)

15. E. Janigacz, Prz. Geolog. 47, 3 (1999)

16. I. Kajewski, Infrastr. Ekol. Ter. Wiejs. 8, 1 (2010)

17. B. Sapek, Woda Środ. Obsz. Wiejs. 6, 1 (2006)

18. J. Jaszczyński, A. Sapek, S. Chrzanowski, Woda Środ. Obsz. Wiejs. 6, 2 (2006)

19. S. Zabłocki, Biuletyn PIG 456, 2 (2013)

20. J. Raczuk, E. Biardzka, M. Michalczyk, Woda Środ. Obsz. Wiejs. 9, 1 (2009)

21. I. Tałałaj, Infrastr. Ekol. Ter. Wiejs. 5, (2008)

22. M. Fic, W. Mioduszewski, Woda Środ. Obsz. Wiejs. 3, 6 (2003)

23. M. Guzik, Przeg. Geolog. 51, 2 (2003)

24. M. Basu, S. Hoshino, S. Hashimoto, Nat. Hazard. Rev. 81, 1 (2016)

25. A.M. Marciniak, P. Wesolowski, A. Brysiewicz, P. Burczyk, J. Elem. 21, 2 (2016)

26. T.Y. Stigter, L. Ribeiro, A.M.M. Carvalho Dill, J. Hydrol. 327, $3 / 4$ (2006)

27. J.W. Chen, H. Qian, Exposure Health 8, 3 (2016)

28. K. Pawęska, B. Malczewska, A. Bawiec, A. Bauerek, JEE 49, (2016)

29. K. Pawęska, B. Malczewska, B. Zyglińska, Proceedings of ECOpole 6, 1 (2012)

30. T.K. Woroniecki, E. Rumasz-Rudnicka, Acta Agroph. 11, 2 (2008)

31. S. Pietrzak, P. Nawalany, Woda Środ. Obsz. Wiejs. 8, 2b (2008)

32. J. Kachnic, Prz. Geolog. 49, 2 (2001)

33. B.G. Katz, D.W. Griffin, P.B. McMahon, H.S. Harden, E. Wade, R.W. Hicks, J.P. Chanton, J. Environ. Qual. 39, 4 (2009)

34. I. Zimoch, J. Paciej, Desalin. Water Treat. 57, 3 (2016)

35. R. Nowak, A. Imperowicz, Inż. Ekol. 47 (2016)

36. M.L. Collin, A.J. Melloul, J. Cleaner Prod. 11, 7 (2003)

37. Z. Yousefi, S. Rouhani, S.M. Ansari Yeganeh, Iranian J. Health Sc. 2, 1 (2014)

38. Regulation of the Minister of Health of 13 November 2015 on the quality of water intended for human consumption, J. Laws, item 1989 (2015)

39. Own study based on data from local water companies

40. Opinion to determine the hydrogeological conditions in the area of groundwater intakes in $\mathrm{C}$ village 